\title{
DISTRIBUSI KEPEMILIKAN LAHAN PERTANIAN DAN PENDAPATAN USAHATANI DI WILAYAH PERKOTAAN KABUPATEN JEMBER
}

\author{
Pravitasari Anjar Pratiwi ${ }^{1}$, Mohammad Rondhi ${ }^{2}$ \\ ${ }^{1}$ Mahasiswa,Program Studi Agribisnis, Fakultas Pertanian, Universitas Jember \\ ${ }^{2}$ Dosen, Program Studi Agribisnis, Fakultas Pertanian, Universitas Jember \\ E-mail: pravita.anjar@gmail.com
}

\begin{abstract}
Conversion of agricultural land to non-agricultural becomes unavoidable, given the high demand for land use to promote economic development. Conversion of agricultural land mostly occurs in urban areas affecting the changing patterns and distribution of agricultural land tenure in urban areas. Higher rents for land in urban areas will trigger land conversion and lead to imbalances in agricultural land tenure. Changes in the distribution of agricultural land will affect farm income, because agricultural land is a valuable asset for farmers and affects their farm income. The purpose of this study was to determine the inequality of agricultural land tenure and farm income in urban areas of Jember. Using analytical method with gini index and descriptive method. Samples were determined by simple random sampling and 43 samples were obtained. The result of the research shows that: (1) land tenure index of agricultural land is 0.52 which means that farm ownership in Jember urban areas is unequal, (2) farm income with gini index 0.46 means that income of farming activity in urban area is uneven.
\end{abstract}

Keywords: land tenure, gini index, income distribution, inequality

\begin{abstract}
Abstrak: Konversi lahan pertanian menjadi non pertanian tidak dapat dihindari, mengingat tingginya permintaan lahan untuk mendukung pengembangan perekonomian. Konversi lahan pertanian pada umumnya terjadi di wilayah perkotaan menyebabkan terjadinya perubahan pola dan distribusi kepemilikan lahan pertanian di wilayah perkotaan. Tingginya nilai sewa lahan pertanian di wilayah perkotaan memicu terjadi konversi dan berdampak pada ketimpangan kepemilikan lahan pertanian. Perubahan distribusi kepemilikan lahan pertanian akan mempengaruhi pendapatan petani, karea lahan pertanian merupakan aset yang berharga bagi petani sehingga akan mempengaruhi pendapatan usahatani mereka. Penelitian ini bertujuan untuk mengetahui ketimpangan kepemilikan lahan pertanian dan pendapatan usahatani di wilayah perkotaan Kabupaten Jember. Analisis data yang digunakan adalah indeks gini dan metode deskriptif. Hasil penelitian menunjukkan bahwa: (1) indeks gini distribusi kepemilikan lahan pertanian sebesar 0.52 yang berarti bahwa kepemilikan lahan pertanian di wilayah perkotaan Kabupaten Jember timpang, (2) pendapatan usahatani dengan indeks gini sebesar 0.46 berarti pendapatan usahatani di wilayah perkotaan kurang merata.
\end{abstract}

Kata kunci: indeks gini, kepemilikan lahan, ketimpangan, pendapatan usahatani

\section{PENDAHULUAN}

Sektor pertanian masih menjadi salah stau sektor yang memiliki peran strategis dalam menggerakkan perekonomian nasional. Menurut Setiawan (2014), peran tersebut ditunjukkan melalui kontribusinya dalam PDB Nasional, penyedia lapangan kerja, penyedia bahan baku industri (leading sector), serta sumber devisa melalui kegiatan ekspor komoditas pertanian. Peranan lain yang hanya mampu diberikan oleh sektor pertanian adalah 
sebagai penyedia sumber bahan pangan bagi kepentingan domestik, karena menurut Soetriono (2006), bahan pangan hanya bisa diciptakan melalui kegiatan di sektor pertanian yang kegiatannya berlandaskan pada pertumbuhan tanaman dan hewan untuk menghasilkan bahan pangan.

Pertanian memiliki peranan yang sangat penting dilihat dari keharusannya memenuhi kebutuhan pangan penduduk yang diprediksikan akan terus bertambah setiap tahunnya. Sementara menurut Malthus laju pertumbuhan penduduk akan selalu lebih cepat dibanding laju pertumbuhan produksi pangan. Hal ini berarti bahwa bahwa pertumbuhan pangan tidak mampu mengimbangi laju pertumbuhan penduduk (Indrayani, 2014).

Permasalahan lain dalam pemenuhan kebutuhan pangan penduduk berkaitan dengan ketersediaan lahan pertanian yang terus mengalami penurunan kualitas dan kuantitas. Penurunan lahan dari segi kuantitas sebagai dampak peningkatan pertumbuhan penduduk, pesatnya pembangunan ekonomi menyebabkan terjadinya persaingan penggunaan lahan untuk berbagai sektor, utamanya untuk sektor non pertanian. Lahan yang secara teori bersifat tetap, sementara seiring dengan pembangunan ekonomi permintaan lahan untuk berbagai kepentingan semakin banyak. Kondisi yang demikian menyebabkan terjadinya alih fungsi lahan pertanian menjadi lahan non pertanian untuk mendukung kegiatan di sektor tersebut..

Alih fungsi lahan pertanian atau yang kemudian dikenal dengan konversi lahan pertanian di suatu wilayah didominasi terjadi di wilayah perkotaan. Wilayah kota merupakan pusat perkembangan wilayah yang akan selalu berkaitan dengan ekspansi atau perluasan untuk menunjang pembangunan di wilayah tersebut. Lahan petanian di wilayah perkotaan akan mudah dialihfungsikan, karena menurut Uchyani dan Aini (2012), dengan memanfaatkan lahan untuk kegiatan non pertanian (indsutri, permukiman, fasilitas, dan lainnya) akan lebih menguntungkan dibandingkan apabila lahan dimanfaatkan untuk kegiatan pertanian sebagai kegiatan terdahulu yang dilakukan untuk memanfaatkan lahan. Wilayah perkotaan sebagai daerah dengan aksesibilitas fisik dan ekonomi yang baik akan menjadi pendorong terjadinya alih fungsi lahan pertanian menjadi non pertanian.
Kabupaten Jember sebagai wilayah di Jawa Timur dengan luas lahan sawah tertinggi kedua, mengalami konversi lahan pertanian sebesar 654,7 ha selama 2005 hingga 2013 yang diperuntukkan sebagian besar untuk pembangunan permukiman penduduk dan terkonsetrasi di wilayah perkotaan (Sunartomo, 2015). Wilayah perkotaan di Kabupaten Jember tersebar pada 3 kecamatan yakni, Sumbersari, Patrang, dan Kaliwates. Sumbersari adalah kecamatan dengan laju konversi yang tinggi dibandingkan kecamatan lainnya. Santoso (2011), menyatakan bahwa selama 2005 hingga 2008 penurunan jumlah lahan pertanian (sawah) adalah sebesar 9,01\%.

Fenomena konversi lahan pertanian menjadi non pertanian di wilayah perkotaan akan berakibat pada perubahan pola distribusi kepemilikan lahan pertanian. Perubahan kepemilikan akan mengarah pada semakin kecilnya lahan yang diusahakan petani dan hanya sebagian kecil petani yang dapat memanfaatkan kesempatan ekonomi yang muncul dengan adanya alih fungsi lahan tersebut di wilayah perkotaan karena semakin banyak lahan pertanian yang dialihfungsikan. Hal ini kemudian menyebabkan distribusi kepemilikan lahan di wilayah perkotaan dengan nilai ekonomi yang tinggi akan cenderung timpang (Supadi dan Susilowati, 2004).

Distribusi kepemilikan lahan pertanian diikur dengan indeks gini dan didapatkan hasil penelitian di Aceh Utara sebesar 0,475 yang berarti terdapat ketimpangan kepemilikan lahan (Daulay, 2013). Ketimpangan kepemilikan lahan pertanian di wilayah kota menunjukkan indeks gini untuk penguasan lahan menunjukkan nilai 0,967 ; penguasaan lahan padi sebesar 0,967; dan penguasaan hak milik mencapai 0,968 (Octiasari, 2011). Ketiga nilai tersebut menunjukkan bahwa di wilayah perkotaan distribusi kepemilikan lahannya berada pada kondisi yang sangat timpang karena lebih dari 0,5 dan semakin mendekati 1 .

Menurut Winarso (2012), lahan merupakan faktor penting bagi penduduk yang kehidupannya masing tergantung pada sektor pertanian. Kepemilikan lahan tidak hanya penting untuk pertanian, tetapi juga bagi penentuan berbagai kebutuhan lain dalam kehidupan bermasyarakat. Lahan tidak hanya berfungsi sebagai aset profuktif akan tetapi sebagai komoditas yang dapat diperjualberikan. 
Hal tersebut menunjukkan bahwa lahan memiliki peranan sebagai aset sekaligus komoditas yang dapat berpindah tangan dan status penguasaannya setiap saat. Perubahan kepemilikan lahan akan mempengaruhi kondisi sosial ekonomi petani, karena kehilangan hak penguasaan dan kepemilikan terhadap suatu lahan.

Distribusi kepemilikan lahan pertanian di suatu wilayah dapat dijadikan sebagai gambaran pemerataan faktor produksi dengan melihat seberapa banyak penduduk yang mampu menguasai lahan smpit dan luas. Melalui hal tersebut dapat juga diketahui bahwa lahan pertanian sebagai sumber pendapatan untuk rumah tangga petani sehingga dapat dijadikan sebagai indikator tingkat kesejahteraan meskipun tidak sepenuhnya dapat mencerminkan tingkat kesejahteraan yang sebenarnya (Saptana dan Rozi, 2014).

Beberapa hasil penelitian memperlihatkan bahwa luas pemilikan lahan berkorelasi positif dengan pendapatan rumah tangga petani. Salah satunya adalah Octiasari (2011), menunjukkan bahwa di Kelurahan Situmekar, Kota Sukabumi didapatkan hubungan yang signifikan antara pendapatan petani dengan luas pengusahaan lahan sawah. Semakin bersar pendapatan usahatani padi, akan semakin meningkat luas pengusahaan lahan sawah mereka.

Penelitian yang dilakukan oleh Murtisari (2015) untuk mengetahui distribusi pendapatan petani jagung di Kabupaten Bone Bolango yang bersumber dari usahatani jagung saja berada dalam kategori timpang sedang yaitu 0,336 , pendapatan yang bersumber dari semua usahatani berada dalam kategori timpang sedang yaitu 0,313 , dan pendapatan yang bersumber dari seluruh sumber-sumber pendapatan. Distribusi pendapatan usahatani di Aceh Utara secara keseluruhan berdasarkan peneltian Daulay (2013), sebesar 0,47 menunjukkan ketimpangan sedang.

Berdasarkan fenomena tersebut penelitian ini bertujuan untuk mengetahui distribusi kepemilikan lahan dan pendapatan ushatani di wilayah perkotaan Kabupaten Jember khususnya di Kecamatan Sumbersari.

\section{METODE PENELITIAN}

Lokasi penelitian ditentukan secara sengaja (purposive methods), yakni di Kelurahan Antirogo, Kecamatan Sumbersari, Kabupaten Jember pada bulan November 2017 hingga Maret 2018. Kecamatan Sumbersari dipilih karena merupakan wilayah perkotaan Kabupaten Jember dengan laju konversi yang tertinggi selama periode 2009 hingga 2016 berdasarkan data BPS Kabupaten Jember yakni sebesar 8,6\% dibandingkan kecamatan lainnya dengan rata-rata konversi sebesar $0,77 \%$ pada periode yang sama. Lokasi penelitian diperkecil di tingkat kelurahan dan dipilih Kelurahan Antirogo karena memiliki luas lahan sawah tertinggi di Kecamatan Sumbersari yakni sebesar 350 ha dibandingkan 6 kelurahan lain yang hanya berkisar 15 hingga 318 ha. Wilayah tersebut juga mengalami konversi lahan pertanian khususnya sawah sebesar $6 \%$ untuk dijadikan bangunan dan halaman pada tahun 2010 hingga 2017 (BPS Jember, 2017). Adanya konversi lahan pertanian yang menyebabkan perubahan distribusi kepemilikan lahan pertanian di Kelurahan Antirogo, Kecamatan Sumbersari, Kabupaten Jember sebagai wilayah perkotaan Kabupaten Jember.

Metode penelitian yang digunakan metode analitik dan deskriptif. Sampel penelitian ditentukan dengan metode simple random sampling pada pemilik lahan pertanian (1.056 orang). Dengan menggunakan error sebesar $15 \%$ didapatkan jumlah sampel petani yang digunakan adalah 43 petani. Analisis data untuk mengetahui ditribusi kepemilikan lahan dan pendapatan usahatani di wilayah perkotaan dengan menghitung indeks gini kepemilikan lahan dan pertanian menurut Iriani (2008) dengan rumus:

$$
\mathrm{G}=1-\sum_{\mathrm{i}=1}^{\mathrm{k}} \mathrm{f}_{\mathrm{i}}\left(\mathrm{Y}_{\mathrm{i}}-\mathrm{Y}_{(\mathrm{i}-1)}\right)
$$

Kriteria pengambilan keputusan :

a. $0<\mathrm{G}<0,19$ kepemilikan lahan pertanian, pendapatan usahatani terdistribusi sangat merata;

b. $0,20<\mathrm{G}<0,35$ kepemilikan lahan pertanian, pendapatan usahatani terdistribusi merata; 
c. $0,36<\mathrm{G}<0,46$ kepemilikan lahan pertanian, pendapatan usahatani kurang merata

d. $0,47<\mathrm{G}<0,70$ kepemilikan lahan pertanian, pendapatan usahatani timpang;

e. $0,71<\mathrm{G}<1$ kepemilikan lahan pertanian, pendapatan usahatani sangat timpang (Todaro et al., 2011).

\section{HASIL DAN PEMBAHASAN}

\section{Karakteristik Responden}

Responden penelitian merupakan petani yang melakukan usahatani selama 1 tahun (3 kali musim tanam) di Kelurahan Antirogo. Karakteristik responden penelitian dikategorikan berdasarkan umur, pendidikan, serta luas dan kepemilikan lahan responden.

Umur responden berada pada usia 41 hingga 65 tahun. Responden yang berada pada usia produktif (15-55 tahun) sejumlah 20 petani atau $46,52 \%$ dari keseluruhan responden, sedangkan 23 responden atau 53,48\% berada di usia tidak produktif. Kondisi ini menunjukkan bahwa sebagian besar responden berada pada usia kurang produktif dan hal ini akan berdampak pada kinerja petani dalam usahatani.

Pendidikan responden yang dimaksud adalah tingkat pendidikan forml terakhir yang telah ditempuh oleh responden. Sebanyak 17 responden $(39,53 \%)$ berpendidikan SMA/sederajat; 14 responden berpendidikan $\mathrm{SD} /$ sederajat; 11 responden berpendidikan $\mathrm{SMP} /$ sederajat; dan 1 responden mampu meneyelesaikan pendidikan hingga perguruan tinggi. Data pendidikan responden menunjukkan bahwa akses pendidikan yang diperoleh oleh petani di daerah penelitian sudah cukup baik, karena banyak petani yang mampu menyelesaikan pendidikan hingga tingkat SMA/sederajat.

Luas lahan keseluruhan responden penelitian adalah 16,3 ha. Sistem kepemilikan yang berlaku di lokasi penelitian ada dua sistem, yakni milik sendiri dan bukan milik sendiri yang terdiri dari sewa dan gaden atau bagi hasil. Berikut ini adalah data yang menunjukkan luas lahan dan kepemilikan petani terhadap lahan tersebut:
Tabel 1. Luas dan kepemilikan lahan pertanian

\begin{tabular}{|c|c|c|c|c|}
\hline \multirow[b]{2}{*}{$\begin{array}{l}\text { Luas lahan } \\
\text { (ha) }\end{array}$} & \multicolumn{4}{|c|}{ Jumlah Responden (orang) } \\
\hline & Milik & Sewa & $\begin{array}{l}\text { Bagi } \\
\text { hasil }\end{array}$ & Total \\
\hline$<0,25$ & 4 & 8 & 0 & 12 \\
\hline $0,25-<0,50$ & 16 & 4 & 1 & 21 \\
\hline $0,50-<0,75$ & 6 & 0 & 0 & 6 \\
\hline $0,75-<1,00$ & 0 & 0 & 0 & 0 \\
\hline $1,00-<2,00$ & 4 & 0 & 0 & 4 \\
\hline$>2,00$ & 0 & 0 & 0 & 0 \\
\hline Total & 30 & 12 & 1 & 43 \\
\hline
\end{tabular}

Sumber: Data primer, 2018

Berdasarkan tabel 1 dapat diketahui bahwa luas lahan tertinggi dimiliki responden adalah 1,0 ha dan terendahnya 0,1 ha. Luas lahan yang dimiliki oleh responden penelitian berada pada kisaran luas lahan 0,25 hingga 1 ha. Petani lebih banyak memiliki lahan dengan kategori agak sempit $(0,25-<0,5$ ha); kemudian lahan sempit $(<0,25)$; sebagian kecil lahan sedang $(0,50-<0,75 \mathrm{ha})$ dan luas $(1,00-$ $<2,00$ ha).

Data tersebut menunjukkan $69,77 \%$ petani mengusahakan lahan yang dimiliki sendiri, sedangkan sisanya 30,23\% bukan milik sendiri (sewa dan bagi hasil). Petani di lokasi penelitian memiliki kecenderungan menyewa lahan dengan luasan yang sempit hingga agak sempit. Hal ini dikarenakan menurut petani di lokasi penelitian dengan melakukan sewa di lahan yang sempit mengurangi resiko apabila terjadi kerugian karena sewa yang dibayarkan di lahan yang sempit tidak begitu banyak.

\section{Distribusi Kepemilikan Lahan Pertanian di Wilayah Perkotaan Kabupaten Jember}

Lahan pertanian di suatu wilayah merupakan aset yang dapat diperjualbelikan sehingga memungkinkan berpindah tangan dan mengalami perbedaan status penguasaannya setiap lahan. Penelitian yang dilakukan pada 43 petani yang melakukan usahatani didapatkan bahwa terdapat 2 jenis kepemilikan yang ada di lokasi penelitian yakni, hak milik dan bukan milik.

Pengukuran distribusi kepemilikan lahan pertanian dihitung dengan menggunakan indeks gini (G). Perhitungan indeks gini untuk menghitung tingkat ketimpangan pada kepemilikan lahan menggunakan rumus yang sama dengan yang digunakan untuk menghitung ketimpangan pendapatan. Hasil perhitungan dengan rumus gini untuk 
kepemilikan lahan pertanian didapatkan hasil bahwa nilai indeks gini untuk lahan yang dimiliki sejumlah 43 petani di lokasi penelitian didapatkan:

Tabel 2. Nilai indeks gini kepemilikan lahan pertanian

\begin{tabular}{llcc}
\hline No & \multicolumn{1}{c}{ Kategori } & $\begin{array}{c}\text { Jumlah } \\
\text { (orang) }\end{array}$ & $\begin{array}{c}\text { Indeks } \\
\text { gini }\end{array}$ \\
\hline 1 & Lahan pertanian & 43 & 0,52 \\
2 & Lahan milik sendri & 30 & 0,49 \\
3 & $\begin{array}{l}\text { Lahan bukan milik } \\
\text { sendiri }\end{array}$ & 13 & 0,55 \\
\hline
\end{tabular}

Sumber: Analisis data primer, 2018

Berdasarkan tabel 2. didapatkan indeks gini lahan pertanian sebesar 0,52 . Indeks gini lahan pertanian dengan kepemilikan milik sendiri sebesar 0,49. Indeks gini lahan pertanian dengan kepemilikan lahan pertanian bukan milik sendiri sebesar 0,55. Nilai indeks kepemilikan lahan pertanian secara keseluruhan dan berdasarkan kepemilikan bukan milik sendiri berada pada interval $0,46<\mathrm{G}=0,49$;
0,$52 ; 0,55<0,70$ yang berarti distribusi kepemilikan lahan di lokasi penelitian timpang. Ilustrasi kurva lorenz terhadap ketimpangan kepemilikan lahan seperti dalam gambar 1 .

Gambar 1. menunjukkan bahwa koefisien gini yang dihitung berada pada posisi menjauhi garis kemerataan. Kondisi tersebut menunjukkan adanya ketimpangan karena menjauhi garis kemerataan. Kurva lorenz untuk ketiga kategori di atas semakin menjauhi garis kemerataan yang berarti bahwa distribusi kepemilikan lahan di lokasi penelitian sangat tidak merata atau timpang.

Gambar kurva lorenz yang menggambarkan kepemilikan lahan bukan milik sendiri berada pada posisi lebih jauh dari garis kemerataan dibandingkan kurva lorenz yang menunjukkan kepemilikan lahan milik sendiri dan kepemilikan lahan keseluruhan, hal ini mengilustrasikan koefisien gini kepemilikan lahan bukan milik sendiri lebih besar dibandingkan kedua kategori lainnya.

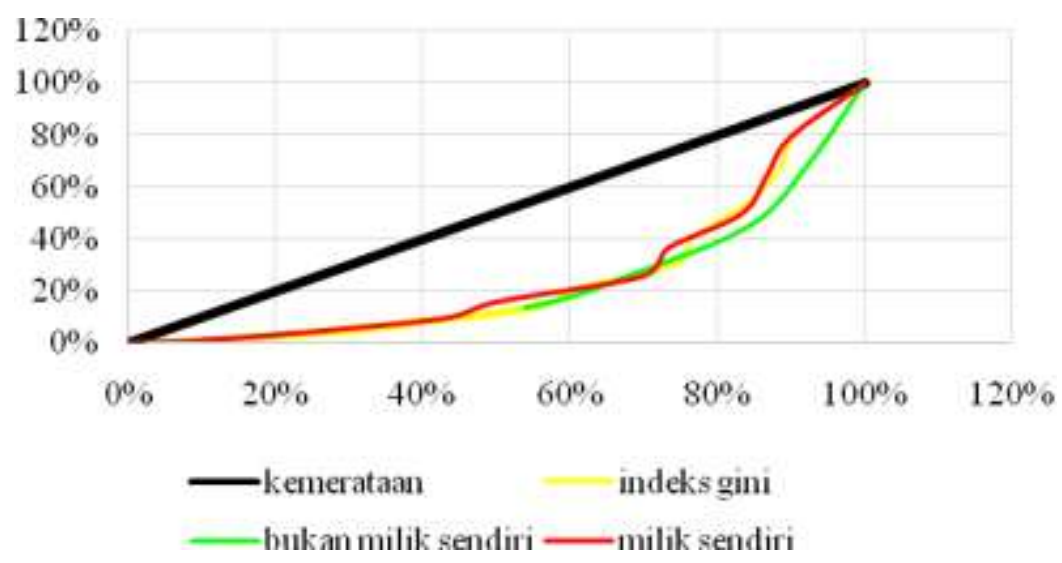

Gambar 1. Kurva Lorenz Distribusi Kepemilikan Lahan Pertanian

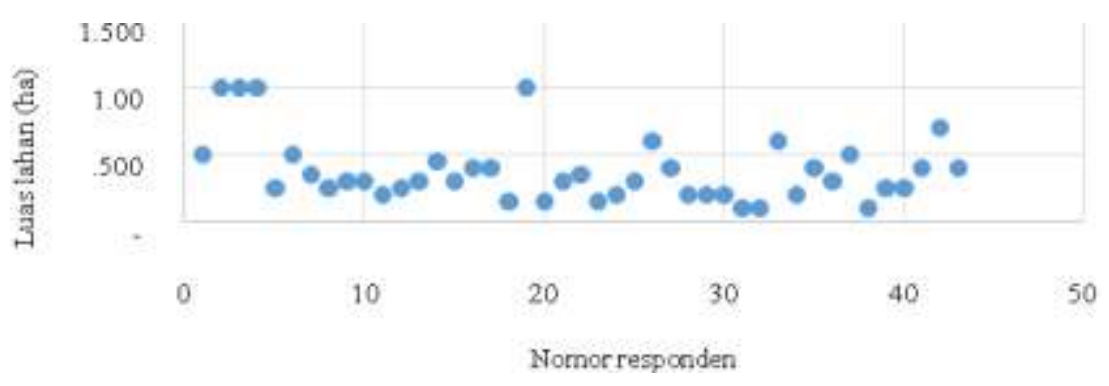

Gambar 2. Sebaran kepemilikan luasan lahan pertanian 
Hal ini menunjukkan bahwa semakin menjauhi garis kemerataan koefisien atau indeks gini semakin tinggi (mendekati 1 atau semakin timpang). Indeks gini lahan pertanian di wilayah perkotaan pada tabel 5.6 serta pada gambar kurva lorenz di atas menunjukkan kondisi lahan tidak terdistribusi dengan merata atau timpang. Hal ini dapat dilihat dari kondisi riil penguasaan lahan seperti dalam gambar 2 .

Berdasarkan gambar 2. diketahui sebaran kepemilikan luasan lahan pertanian. Mayoritas petani yakni lebih dari $50 \%$ petani responden di lokasi penelitian melakukan usahatani dengan luas lahan pada kisaran < 0,60 ha; dan hanya sebagian kecil petani yang melakukan usahatani pada luas lahan $\geq 0,60$ ha. Petani melakukan usahatani pada lahan yang sempit ( $<0,25$ ha) adalah sebanyak 12 orang atau $27,91 \%$; petani yang melakukan usahatani pada lahan agak sempit $(0,25-<0,50$ ha) sejumlah $48,84 \%$ atau sekitar 21 petani; sebanyak 6 petani atau $13,95 \%$ melakukan usahatani di lahan sedang $(0,50-<0,75)$; dan sisanya sebanyak 4 orang atau $9,30 \%$ melakukan usahatani di lahan luas $(1,00-2,00$ ha $)$. Kondisi tersebut menggambarkan ketimpangan kepemilikan lahan dari segi luas lahan yang dimiliki, dimana pada lahan yang sempit hingga agak sempit dimiliki oleh $76,75 \%$ petani (sebagian besar petani), sedangkan petani yang memiliki luas lahan sedang hingga luas hanya $23,25 \%$ (sebagian kecil petani). Hal ini menunjukkan bahwa terjadi ketimpangan, dimana luas lahan yang tinggi hanya dimiliki oleh sebagian kecil petani, sedangkan luas lahan rendah dimiliki oleh sebagian besar petani.

Lebih rendahnya indeks gini lahan yang dimiliki sendiri dibandingkan lahan yang bukan milik sendiri dikarenakan sebaran kepemilikan lahan dengan status bukan milik sendiri cenderung tersebar tidak merata. Lahan milik sendiri dengan luasan yang tinggi dimiliki oleh beberapa orang petani, sedangkan sedikit sekali petani yang mampu menyewa lahan dengan luasan yang tinggi. Sementara untuk lahan yang sempit disewa oleh banyak petani. Lebih timpangnya distribusi kepemilikan lahan pertanian dengan status bukan milik sendiri dikarenakan adanya pencilan data (outlier) yang menunjukkan adanya petani mampu menyewa lahan pada luasan yang tinggi. Berikut ini adalah data yang menunjukkan perbedaan kepemilikan lahan untuk tiap luasan lahan: Tabel 2. Sebaran luas lahan berdasarkan

\begin{tabular}{ccc}
\hline \multirow{2}{*}{$\begin{array}{c}\text { Luas lahan } \\
\text { (ha) }\end{array}$} & \multicolumn{2}{c}{ Jumlah petani (orang) } \\
\cline { 2 - 3 } & Milik sendiri & sewa \\
\hline 0,1 & 2 & 1 \\
0,15 & 1 & 2 \\
0,2 & 2 & 4 \\
0,25 & 3 & 2 \\
0,3 & 5 & 2 \\
0,35 & 2 & - \\
0,4 & 6 & - \\
0,45 & 1 & - \\
0,5 & 3 & - \\
0,6 & 1 & 1 \\
0,7 & 1 & - \\
1 & 3 & 1 \\
\hline Total & 30 & 13 \\
\hline
\end{tabular}

Sumber: Data primer diolah, 2018

Berdasarkan perhitungan indeks gini kepemilikan lahan pertanian dan didapatkan nilai 0,52; ilustrasi kurva lorenz berada di bawah garis kemerataan; sebaran luasan lahan yang dikuasai oleh petani menunjukkan hasil adanya ketimpangan distribusi kepemilikan lahan. Lahan yang luas hanya dimiliki sebagian kecil petani dan sebaliknya. Distribusi kepemilikan lahan pertanian di wilayah perkotaan Kabupaten Jember timpang.

\section{Distribusi Pendapatan Usahatani di Wilayah Perkotaan Kabupaten Jember}

Pendapatan usahatani yang akan dianalisis merupakan pendapatan yang diperoleh petani dalam satu tahun mengusahakan lahan yang dimiliki atau disewa oleh mereka. Dalam satu tahun petani di lokasi penelitian akan melakukan tiga kali penanaman. Musim pertama atau yang dikenal dengan musim hujan 1 November - Februari, petani akan menanam komoditas padi seara serempak. Musim kedua atau musim kemarau 1 pada Bulan Maret - Juni petani akan tetap menanam padi. Musim ketiga yang berlangung pada Juli - Oktober ada beberapa pilihan komoditas yang ditanam petani yakni dapat berupa jagung atau tembakau.

Responden penelitian sejumlah 43 orang menerapkan dua pola tanam, yakni padi - padi - jagung sebanyak 28 orang dan padi - padi tembakau sebanyak 15 orang pada tahun 2017. 
Perhitungan pendapatan dilakukan dengan menjumlah semua penerimaan pada ketiga musim, kemudian dikurangi dengan biaya variabel pada tiga musim serta biaya tetap yang meliputi alat dan sewa atau pajak lahan. Tabel 3 menunjukkan rata-rata pendapatan usahatani berdasarkan pola tanam yang diterapkan petani. Hasil perhitungan pendapatan pada 43 responden dengan pola tanam yang berbeda didapatkan pada tabel 3 terdapat perbedaan rata-rata pendapatan usahatani dengan pola tanam padi - padi - jagung dan padi - padi tembakau. Petani yang menerapkan pola tanam padi - padi - tembakau memperoleh rata-rata pendapatan per usahatani rata-rata sebesar $\mathrm{Rp}$ 31.799.332,00/orang/tahun lebih besar hingga tiga kali lipat dibandingkan petani yang menerapkan pola tanam padi - padi - jagung dengan rata-rata pendapatan per tahun sebesar $\mathrm{Rp} 10.592 .054,00 /$ orang/tahun. Rata-rata pendapatan per luas lahan petani yang menerapkan pola tanam padi - padi - tembakau sebesar Rp 27.113.610,00/ha/tahun juga lebih tinggi tiga kali lipat daripada pendapatan petani yang menerapkan pola tanam padi - padi jagung hanya sebesar Rp 9.880.191,00/ha/tahun. Lebih tingginya pendapatan yang diperoleh petani yang menanam tembakau pada musim tanam tiga karena produksi tembakau pada saat itu bagus dan harga yang ditawarkan perusahaan juga tinggi sehingga pendapatannya cukup besar.

Nilai indeks gini pendapatan usahatani dihitung dengan rumus yang sama untuk menghitung indeks gini kepemilikan lahan pertanian. Terlebih dahulu dilakukan kategorisasi untuk pendapatan usahatani secara umum dan berdasarkan pola tanam yang diterapkan petani. Pengkategorian pendapatan dibedakan menjadi sembilan kelas seperti dalam tabel 4.

Data pada tabel 4 menunjukkan bahwa pada pola tanam 1 yakni padi - padi - jagung, pendapatan petani hanya pada kategori 1 hingga 3 yang berarti bahwa pendapatan dari usahatani tersebut berkisar Rp 0 hingga $\mathrm{Rp} 29$ juta per tahun.

Tabel 4. Distribusi pendapatan usahatani berdasarkan pola tanam

\begin{tabular}{cccc}
\hline & \multicolumn{3}{c}{ Jumlah petani (orang) } \\
\cline { 2 - 4 } Kategori & Pola & Pola & \\
pendapatan & $\begin{array}{c}\text { tanam } \\
\text { tanam }\end{array}$ & Total \\
\hline 10.000 .000 & 13 & 3 & 16 \\
$10.000 .000-$ & 9 & 5 & 14 \\
19.999 .999 & & & \\
$20.000 .000-$ & 3 & 5 & 8 \\
29.999 .999 & & & \\
$30.000 .000-$ & 0 & 1 & 1 \\
39.999 .999 & & & \\
$40.000 .000-$ & 0 & 2 & 2 \\
49.999 .999 & & & \\
$50.000 .000-$ & 0 & 0 & 0 \\
59.999 .999 & & & \\
$60.000 .000-$ & 0 & 0 & 0 \\
69.999 .999 & & & \\
$70.000 .000-$ & 0 & 1 & 1 \\
79.999 .999 & & & 16 \\
$80.000 .000-$ & 0 & 1 & 18 \\
89.999 .999 & & 25 & 18
\end{tabular}

Sumber: Data primer diolah, 2018.

Ket: Pola tanam $1=$ padi - padi - jagung

Pola tanam $2=$ padi - padi - tembakau

Sedangkan untuk pola tanam 2 yakni padi - padi - tembakau, pendapatan usahatani cukup bervariasi karena tersebar hampir pada semua kategori. Apabila dibandingkan dengan pola tanam 1, dapat diketahui bahwa usahatani dengan pola tanam 2 lebih menguntungkan karena banyak petani yang mampu merasakan pendapatan yang tinggi yakni pada kategori 2 hingga 9 sebagai kategori pendapatan tertinggi. Distribusi yang tergambar pada tabel 4 menunjukkan bahwa distribusi pendapatan yang menerapkan pola tanam 1 cenderung lebih merata dibandingkan pada pola tanam 2 .

Tabel 3. Rata-rata pendapatan usahatani berdasarkan pola tanam per usahatani dan luas lahan

\begin{tabular}{|c|c|c|c|c|c|}
\hline \multirow[b]{2}{*}{ No } & \multirow[b]{2}{*}{ Pola tanam } & \multirow{2}{*}{$\begin{array}{l}\text { Jumlah } \\
\text { Petani } \\
\text { (orang) }\end{array}$} & \multirow{2}{*}{$\begin{array}{c}\text { Rata-rata luas } \\
\text { lahan (ha) }\end{array}$} & \multicolumn{2}{|c|}{ Rata-rata pendapatan } \\
\hline & & & & $\begin{array}{c}\text { Per usahatani } \\
\text { (Rp/orang/tahun) }\end{array}$ & $\begin{array}{l}\text { Per luas lahan } \\
\text { (Rp/ha/tahun) }\end{array}$ \\
\hline 1 & Padi - padi - jagung & 25 & 0,352 & 10.592 .054 & 9.880 .191 \\
\hline 2 & Padi - padi - tembakau & 18 & 0,414 & 31.799 .332 & 27.113 .610 \\
\hline
\end{tabular}


Berikut ini adalah hasil perhitungan indeks gini untuk mengetahui ketimpangan pendapatan usahatani secara keseluruhan dan berdasarkan pola tanam yang diterapkan:

Tabel 5. Nilai indeks gini pendapatan usahatani

\begin{tabular}{llcc}
\hline No & \multicolumn{1}{c}{$\begin{array}{c}\text { Kategori } \\
\text { pendapatan }\end{array}$} & $\begin{array}{c}\text { Jumlah } \\
\text { (orang) }\end{array}$ & Indeks gini \\
\hline 1 & Keseluruhan & 43 & 0,46 \\
& pendapatan petani & & \\
2 & Pola tanam 1 & 25 & 0,38 \\
3 & Pola tanam 2 & 18 & 0,44 \\
\hline
\end{tabular}

Sumber: Analisis data primer, 2018

Ket: Pola tanam $1=$ padi - padi - jagung

Pola tanam $2=$ padi - padi - tembakau

Hasil analisis distribusi pendapatan usahatani dengan indeks gini pada tabel 5 sebesar 0,46 . Indeks gini pendapatan usahatani dengan pola tanam 1 dan 2 berturut-turut 0,38 dan 0,44 . Ketiga nilai tersebut berada pada 0,36 $<\mathrm{G}=0,38 ; 0,44 ; 0,46 \leq 0,46$ sehingga distribusi pendapatan usahatani di wilayah perkotaan kurang merata. Secara keseluruhan pendapatan usahatani kurang merata karena $(\mathrm{G}$ $=0,46)$ pada tabel 4 dapat diketahui bahwa terdapat sedikit petani yang mampu memperoleh pendapatan sangat tinggi sedangkan banyak petani lainnya hanya mendapatkan pendapatan yang rendah hal inilah yang disebut kurang meratanya pendapatan usahatani. Nilai indeks gini untuk pendapatan usahatani dengan pola tanam 2 sebesar 0,44 karena distribusi pendapatannya pada tabel 5 juga kurang merata sama halnya dengan pendapatan usahatani secara keseluruhan. Berbeda dengan indeks gini pendapatan usahatani dengan pola tanam 1 hanya 0,38 yang berarti ketimpangannya lebih rendah dan dapat ditunjukkan pada tabel 5 bahwa pendapatan usahatani tersebut cenderung merata karena hanya pada 3 kategori pendapatan saja sehingga gap pendapatan tidak terlalu tinggi. Akan tetapi nilai tersebut masih termasuk kurang merata karena masih banyak petani yang pendapatan usahataninya rendah, dan beberapa petani pendapatannya bisa tinggi. Untuk memperjelas perbedaan ketiga nilai indeks gini dapat dilihat melalui kurva lorenz pada gambar 3:

Kurva lorenz pada gambar 3 menunjukkan adanya tiga ilustrasi indeks gini yang mewakili masing-masing kategori. Pendapatan usahatani seara keseluruhan dengan nilai indeks gini 0,46 terlihat semakin menjauhi garis kemerataan. Kurva lorenz pendapatan usahatani dengan pola tanam 1 lebih mendekati garis kemerataan dibandingkan 2 kurva lorenz lainnya karena nilai indeks gininya lebih kecil sebesar 0,38. Pola tanam 2 lebih menjauhi garis kemerataan dibandingkan pendapatan dengan pola tanam 1 dan lebih mendekati garis kemerataan dibandingkan pendapatan secara keseluruhan dengan nilai indeks gini 0,44.

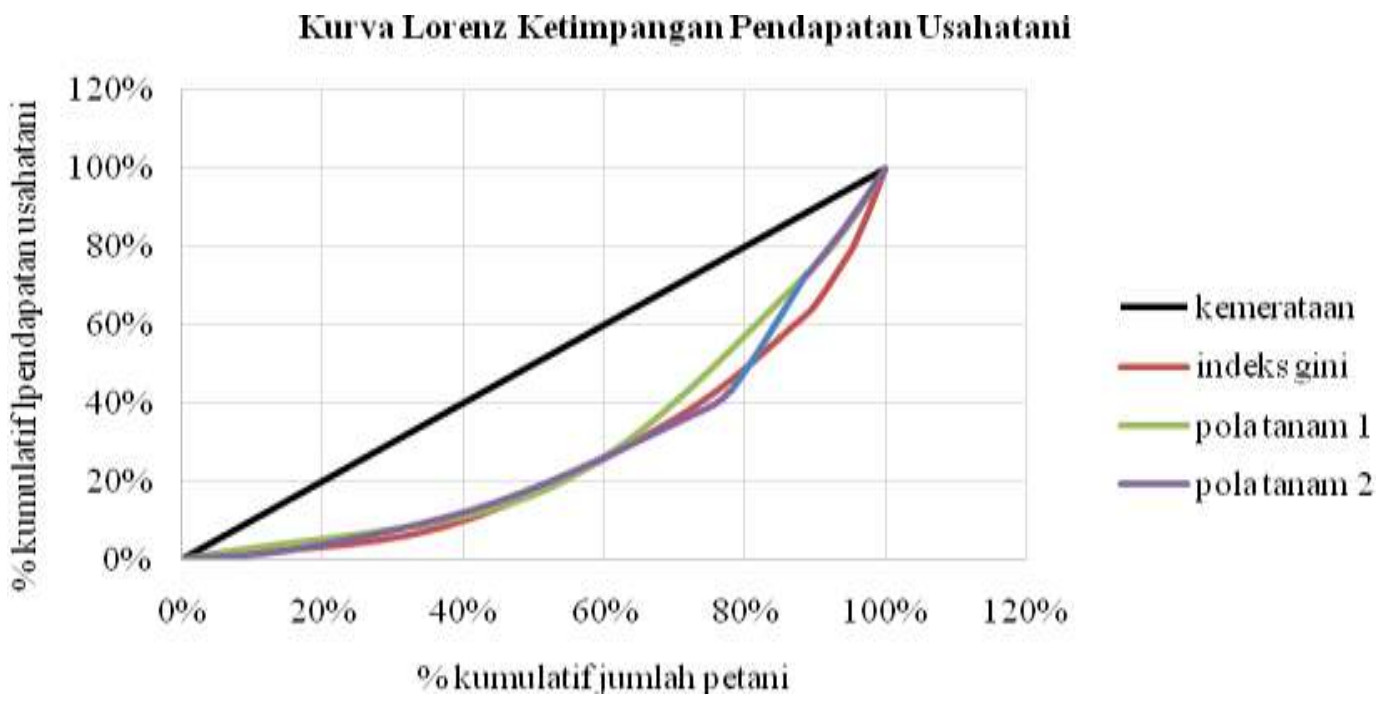

Gambar 3. Kurva lorenz distribusi pendapatan usahatani 
Hal ini berarti pola tanam padi - padi jagung memiliki distribusi yang lebih merata dibandingkan pola tanam padi - padi tembakau maupun pola tanam secara keseluruhan.

Hasil indeks gini kepemilikan lahan pertanian sebesar 0,52 yang berarti distribusi kepemilikan lahan pertanian timpang dan indeks gini pendapatan usahatani sebesar 0,46 yang berarti terdistribusi kurang merata. Keduanya memiliki keterkaitan karena dengan banyaknya petani yang mengusahakan usahataninya di lahan yang sempit akan berdampak pada sedikitnya pendapatan yang mereka peroleh. Sementara hanya sebagian kecil petani yang mampu mengusahakan lahan yang luas dengan pola tanam yang menguntungkan sehingga mereka mampu memperoleh pendapatan yang besar. Hal inilah yang menyebabkan distribusi pendapatan usahatani kurang merata. Terlebih lagi adanya konversi lahan pertanian yang semakin memperkecil kesempatan bagi petani di wilayah perkotaan untuk memperluas usahatani dan memaksimalkan pendapatan mereka.

\section{KESIMPULAN DAN SARAN}

\section{Kesimpulan}

Penurunan luas lahan sawah yang terjadi wilayah perkotaan Kabupaten Jember berdampak pada semakin timpangnya distribusi kepemilikan lahan di wilayah perkotaan Kabupaten Jember dengan nilai indeks gini 0,52. Nilai tersebut menunjukkan bahwa distribusi kepemilikan lahan pertanian di wilayah perkotaan Kabupaten Jember timpang. Ketimpangan kepemilikan lahan pertanian juga berdampak pada kurang meratanya distribusi pendapatan usahatani di wilayah perkotaan dengan nilai indeks gini 0,46 (pendapatan usahatani kurang merata). Hasil penelitian yang menunjukkan adanya ketimpangan kepemilikan lahan di wilayah perkotaan Kabupaten Jember secara tidak langsung merupakan dampak dari adanya konversi lahan pertanian di wilayah yang bersangkutan.

\section{Saran}

Upaya yang dapat dilakukan petani untuk mengurangi ketimpangan pendapatan usahatani mereka adalah dengan memilih pola tanam yang mamu memberikan keuntungan maksimal, serta pemerintah sebaiknya melakukan pengawasan terhadap pelaksanaan RTRW daerah agar tindakan pengalihfungsian lahan pertanian dapat diminimalisir agar distribusi kepemilikan lahan pertanian yang timpang akibat adanya konversi lahan pertanian di wilayah perkotaan dapat diminimalkan.

\section{DAFTAR PUSTAKA}

BPS Kabupaten Jember. 2017. Kecamatan Sumbersari dalam Angka 2016. Jember: Badan Pusat Statistik Kabupaten Jember.

Daulay, H. 2013. Analisis Keterkaitann Distribusi Penguasaan Lahan Usahatani Dengan Distribusi Pendapatan Petani Perdesaan (Studi Kasus diKabupaten Aceh Utara, Propinsi Aceh). Skripsi Sarjana. Bogor: Sekolah Pasca Sarjana, Institut Pertanian Bogor.

Indrayani, A.R.A. 2010. Ketahanan pangan nasional dan teori "Population Trap". Efektif, 1(1): 87-88.

Iriani, A.Y. 2008. Distribusi Kepemilikan Lahan Pertanian Dan Sistem Tenurial Di Desa-Kota (Kasus Desa Cibatok 1, Kecamatan Cibungbulang, Kabupaten Bogor, Propinsi Jawa Barat). Skripsi. Bogor: Program Studi Komunikasi Dan Pengembangan Masyarakat Fakultas Pertanian Institut Pertanian Bogor

Murtisari, A. 2015. Pendapatan, Sumber, dan Distribusi Pendapatan Rumah Tangga Petani Jagung di Kabupaten Bone Bolango. Jurnal Perspektif Pembiayaan dan Pembangunan Daerah, 2(3): 129134.

Octiasari. 2011. Hubungan Status Pengusahaan Lahan dengan Pendapatan Usahatai Padi (Studi Kasus Kelompok Tani Harum IV Kelurahan Situmekar Kecamatan Lembursitu, Kota Sukabumi). Skripsi Sarjana. Bogor: Departemen Agribisnis, Fakultas Ekonomi dan Manajemen, Institut Pertanian Bogor.

Santoso, E. 2011. Kajian Dinamika Konversi Lahan Pertanian Kabupaten Jember. Jurnal ISEI, 2(10): 139-157. 
Saptana, dan A.M.A.Rozi. 2014. Dinamika Ketimpangan Penguasaan Lahan dan Pasar Lahan pada Desa Lahan Kering Berbasis Petani. Panel Petani Nasional: Mobilisasi Sumber Daya dan Penguatan Kelembagaan Pertanian Ketersediaan dan Penguasaan Lahan Pertanian. Jakarta: Pusat Sosial Ekonomi Pertanian Badan Penelitian dan Pengembangan Kementerian Pertanian.

Setiawan, A. 2014. Posisi Pertanian Yang Tetap Strategis Masa Kini dan Masa Depan. http://setkab.go.id/posisipertanian-yang-tetap-strategis-masa-kinidan-masa-depan/. [Diakses pada 16 September 2017].

Soetriono, A. Suwandari, dan Rijanto. 2006. Pengantar Ilmu Pertanian. Malang: Bayu Media.
Sunartomo, A.F. 2015. Pengembangan Konversi Lahan Pertanian di Kabupaten Jember, Agrekonomika, 4(1): 22-36.

Supadi dan S.H. Susilowati. 2004. Dinamika Penguasaan Lahan Pertanian di Indonesia. Bogor: Badan Penelitian dan Pengembangan Pertanian.

Todaro, M. P., and S.C. Smith. 2011. Economic Development (Eleventh Edition). New Jersey: Prentice Hall.

Uchyani, R., dan S.W. Aini. 2012. Tren Alih Fungsi Lahan Pertanian di Kabupaten Klaten. SEPA, 8(2): 51-58.

Winarso, B. 2012. Dinamika Pola Penguasaan Lahan Sawah di Wilayah Pedesaan di Indonesia. Jurnal Penelitian Pertanian Terapan, 12(3): 137-149. 